\title{
Physical exercise among patients with systemic autoimmune myopathies
}

\author{
Diego Sales de Oliveira ${ }^{1}$, Rafael Giovani Misse ${ }^{1}$, Fernanda Rodrigues Lima ${ }^{2}$ and Samuel Katsuyuki Shinjo ${ }^{* *}$
}

\begin{abstract}
Systemic autoimmune myopathies (SAMs) are a heterogeneous group of rare systemic autoimmune diseases that primarily affect skeletal muscles. Patients with SAMs show progressive skeletal muscle weakness and consequent functional disabilities, low health quality, and sedentary lifestyles. In this context, exercise training emerges as a non-pharmacological therapy to improve muscle strength and function as well as the clinical aspects of these diseases. Because many have feared that physical exercise exacerbates inflammation and consequently worsens the clinical manifestations of SAMs, it is necessary to evaluate the possible benefits and safety of exercise training among these patients. The present study systematically reviews the evidence associated with physical training among patients with SAMs.
\end{abstract}

Keywords: Dermatomyositis, Physical exercise, Myositis, Polymyositis

\section{Background}

Systemic autoimmune myopathies (SAMs) are a heterogeneous group of rare autoimmune systemic diseases that primarily affect skeletal muscles [1,2]. Depending on demographic, clinical, laboratory, histopathological, and evolutionary data, SAMs can be subdivided into dermatomyositis (DM), polymyositis (PM), inclusion body myositis (IBM), and others [3].

Patients with SAMs share a common clinical presentation characterized by skeletal muscle weakness, which ultimately leads to functional disability and increased morbidity and mortality [4].

Until the 1960s, absolute rest was recommended for patients with autoimmune rheumatic diseases to help treat the disease [5]. However, this recommendation has changed because sedentary behavior is now known to be associated with increases in triglyceride levels, blood pressure, insulin resistance, and cardiovascular risk $[6,7]$. In this context, exercise training emerged as a nonpharmacological therapy for patients with SAMs, thereby contributing to the restoration of the muscle strength and functional capacity of these individuals and improving their clinical condition. Because exercise training among

\footnotetext{
* Correspondence: samuel.shinjo@gmail.com

${ }^{1}$ Division of Rheumatology, Faculdade de Medicina FMUSP, Universidade de Sao Paulo, Av. Dr. Arnaldo, 455, $3^{\circ}$ andar, sala 3150 - Cerqueira César, Sao

Paulo 01246-903, Brazil

Full list of author information is available at the end of the article
}

these patients was prohibited for many years, it is necessary to understand the mechanisms through which physical exercise acts to improve these parameters, as well as the safety of recommending exercise training to treat these diseases. Thus, the purpose of this review was to describe the safety of exercise training among patients, particularly those with SAMs.

\section{Methods}

For the present study, a bibliographic search was performed using the electronic databases Medline and PubMed.

The descriptors were selected in January 2017 and were defined based on the following keywords (in English): dermatomyositis, inclusion body myositis, polymyositis, idiopathic inflammatory myopathies, aerobic capacity, muscle strength, functional capacity, physical activity, exercise training, resistance training, vascular occlusion training, and resistance training with vascular occlusion. These keywords were combined using the Boolean operators "AND" and "OR" and adapted to each database as needed. In addition, the reference lists of all retrieved articles were manually reviewed.

The following inclusion criteria were adopted: no time limit; published in English; original articles, case reports, case series, controlled clinical trials, or longitudinal experimental studies (with experimental and control groups); exercise/physical training interventions were conducted for 
individuals with SAMs; details of the intervention, such as duration, frequency, types of exercise and intensity, were listed; and muscle strength and/or functionality were evaluated and presented as primary or secondary outcomes through physical performance tests.

Abstracts of congresses, monographs, theses and dissertations, articles about other myopathies (e.g., muscular dystrophy, metabolic myopathy, and neuromuscular disease), and letters to the editor that were purely commentary were excluded from this review.

The search identified 26 articles. The concepts used in this study are explained in Table 1.

\section{Literature review}

The first studies that evaluated the effect of physical exercise on patients with SAMs were performed in the 1990s by Hicks et al. [8] (Table 2) and Escalante et al. [9] (Table 3). Hicks et al. [8] demonstrated that a 4-week quadriceps and biceps isometric strengthening program for patients with PM effectively increased isometric strength without increasing muscle enzyme serum levels. Escalante et al. [9] were the first to suggest that patients with active SAMs can participate in rehabilitation programs involving strength training. Furthermore, these programs were associated with a clinical improvement in strength without increasing muscle enzyme serum levels.

Wiesinger et al. [10] was the first to conduct a prospective, controlled, and randomized study evaluating the effects of physical training on patients with SAMs. In that study, 14 patients with DM/PM (seven undergoing physical training and seven controls) were prospectively evaluated over a 6-week period. Patients undergoing physical training demonstrated significant improvements in aerobic capacity, isometric muscle strength, activities of daily living, and quality of life compared with the control group. In addition, patients undergoing physical training showed an elevation in the inflammatory markers of the disease, suggesting that physical training is safe for these patients. Several additional studies have built on those preliminary studies to better understand the effects of physical training among patients with SAMs.

\section{Physical exercise among patients with DM/PM}

Patients with DM/PM have decreased aerobic capacity, with a lower peak oxygen consumption $\left(\mathrm{VO}_{2}\right.$ peak) [11, 12]. In addition, this decrease in aerobic capacity is positively correlated with a decrease in isometric strength, suggesting that the decrease in muscle strength among these patients impairs aerobic capacity [11].

The impairment in the aerobic capacity of these patients might also be related to elevated levels of blood lactate and the low proportion of type 1 muscle fibers, suggesting that patients with DM/PM show an impaired skeletal muscle oxidative capacity [13, 14]. Because one of the causes of mortality among patients with SAMs is cardiopulmonary diseases $[15,16]$ and decreases in aerobic capacity are associated with an increased risk of these diseases $[17,18]$, it is essential to employ strategies that can improve these parameters among these patients.

Based on this assumption, Wiesinger et al. [19] studied eight patients with $\mathrm{DM} / \mathrm{PM}$ in remission who engaged in a physical training program. These authors observed a $28 \%$ improvement in aerobic capacity after 6 months of training, which was considered clinically significant. The same authors [10] demonstrated a significant improvement in aerobic capacity after 6 weeks of physical training among 14 patients with DM/PM (7 in the training group and 7 controls) in a randomized study. Munters

Table 1 Concepts used in physical training

\begin{tabular}{|c|c|}
\hline Term & Concept \\
\hline Aerobic capacity & $\begin{array}{l}\text { Maximum capacity of the individual to capture oxygen from the environment, transport it through the bloodstream, } \\
\text { and use it in cellular respiration. It can be estimated using peak oxygen consumption (peak } \mathrm{VO}_{2} \text { ) via ergospirometry }\end{array}$ \\
\hline Aerobic training & $\begin{array}{l}\text { Training characterized by low and moderate intensity efforts with a prolonged duration (over } 150 \mathrm{~s} \text { ). This training } \\
\text { predominantly uses oxygen }\left(\mathrm{O}_{2}\right) \text {-dependent bioenergetic pathways to meet the energy demand required by the } \\
\text { activity }\end{array}$ \\
\hline $1 \mathrm{RM}$ & $\begin{array}{l}\text { Test used to determine the maximum muscle strength of the individual, determined as the maximum amount of } \\
\text { weight lifted in only one repetition during a standardized exercise }\end{array}$ \\
\hline MVC & $\begin{array}{l}\text { Test used to determine the maximum number of repetitions/contractions that the participant can perform with a } \\
\text { preset load }\end{array}$ \\
\hline Strength training & $\begin{array}{l}\text { Training that uses exercises requiring a level of strength above that used in everyday tasks to increase muscle } \\
\text { function. When prescribing this training, the 1RM and/or MVC test is necessary, and the training is based on the } \\
\text { percentage of each participant's 1RM (usually between } 50 \text { and } 80 \% \text { of 1RM/MVC) }\end{array}$ \\
\hline Isometric exercise & $\begin{array}{l}\text { During this exercise, the production of muscle tension equals the external load imposed on the muscle. Moreover, } \\
\text { this exercise is characterized by the absence of joint movement during its execution }\end{array}$ \\
\hline Dynamic exercise & $\begin{array}{l}\text { This exercise involves the displacement of the body in time and space, and it is characterized by alternations } \\
\text { between eccentric and concentric contractions }\end{array}$ \\
\hline
\end{tabular}


Table 2 Physical exercise in patients with chronic stable dermatomyositis, polymyositis, or both

\begin{tabular}{|c|c|c|c|c|c|c|}
\hline Author & $\begin{array}{l}\text { Patients } \\
(n)\end{array}$ & $\begin{array}{l}\text { Protocol } \\
\text { (Exercises) }\end{array}$ & $\begin{array}{l}\text { Time } \\
\text { (week) }\end{array}$ & Evaluated Components & Inflammatory markers & Results \\
\hline Hicks et al. [8] & 1 & $\begin{array}{l}\text { Isometric } \\
\text { strength }\end{array}$ & 4 & $\begin{array}{l}\text { Isometric strength } \\
3 \mathrm{MVC}\end{array}$ & $\leftrightarrow \mathrm{CPK}$ & $\uparrow$ Isometric strength \\
\hline $\begin{array}{l}\text { Wiesinger et al. } \\
\text { [10] }\end{array}$ & 14 & Aerobic & 6 & $\begin{array}{l}\mathrm{VO}_{2} \text { peak } \\
\text { Isometric strength } \\
\text { Activities of daily living }\end{array}$ & $\leftrightarrow \mathrm{CPK}$ & $\begin{array}{l}\uparrow \mathrm{VO}_{2} \text { peak } \\
\uparrow \text { Isometric strength } \\
\uparrow \text { Activities of daily living }\end{array}$ \\
\hline $\begin{array}{l}\text { Wiesinger et al. } \\
\text { [19] }\end{array}$ & 13 & Aerobic & 24 & $\begin{array}{l}\mathrm{VO}_{2} \text { peak } \\
\text { Isometric strength } \\
\text { Activities of daily living }\end{array}$ & $\leftrightarrow \mathrm{CPK}$ & $\begin{array}{l}\uparrow \mathrm{VO}_{2} \text { peak } \\
\uparrow \text { Isometric strength } \\
\uparrow \text { Activities of daily living }\end{array}$ \\
\hline $\begin{array}{l}\text { Alexanderson } \\
\text { et al. [23] }\end{array}$ & 10 & $\begin{array}{l}\text { Strength } \\
\text { Dynamic }\end{array}$ & 12 & $\begin{array}{l}\text { Muscle function } \\
\text { Walking distance } \\
\text { Quality of life }\end{array}$ & $\begin{aligned} \leftrightarrow & \text { CPK } \\
\leftrightarrow & \text { Immune / } \\
& \text { inflammatory } \\
& \text { markers }\end{aligned}$ & $\begin{array}{l}\uparrow \text { Muscle function } \\
\uparrow \text { Walking distance } \\
\uparrow \text { Quality of life }\end{array}$ \\
\hline $\begin{array}{l}\text { aHeikkilä et al. } \\
\text { [44] }\end{array}$ & 22 & $\begin{array}{l}\text { Strength } \\
\text { Dynamic }\end{array}$ & 3 & $\begin{array}{l}\text { Functional capacity } \\
\text { Pain }\end{array}$ & $\leftrightarrow \mathrm{CPK}$ & $\begin{array}{l}\uparrow \text { Muscle function } \\
\leftrightarrow \text { Pain }\end{array}$ \\
\hline $\begin{array}{l}\text { b Varvu et al. } \\
\text { [45] }\end{array}$ & 19 & $\begin{array}{l}\text { Strength } \\
\text { Dynamic }\end{array}$ & 3 & $\begin{array}{l}\text { Respiratory function } \\
\text { (Spirometry) } \\
\text { Muscle strength }\end{array}$ & $\leftrightarrow \mathrm{CPK}$ & $\begin{array}{l}\uparrow \text { Respiratory function } \\
\uparrow \text { Muscle function }\end{array}$ \\
\hline $\begin{array}{l}\text { Harris-Love et al. } \\
\text { [46] }\end{array}$ & 1 & $\begin{array}{l}\text { Strength } \\
\text { Eccentric }\end{array}$ & 12 & Isometric strength & $\leftrightarrow$ Muscle enzymes & $\begin{array}{l}\uparrow \text { Isometric strength } \\
\uparrow \text { Concentric strength }\end{array}$ \\
\hline $\begin{array}{l}\text { Alexanderson } \\
\text { et al. [23] }\end{array}$ & 8 & $\begin{array}{l}\text { Strength } \\
\text { Dynamic }\end{array}$ & 7 & $\begin{array}{l}\text { 10-15 MVC } \\
\text { Functional capacity }\end{array}$ & $\leftrightarrow \mathrm{CPK}$ & $\begin{array}{l}\uparrow 10-15 \text { MVC } \\
\leftrightarrow \text { Disease activity } \\
\leftrightarrow \text { Functional capacity }\end{array}$ \\
\hline $\begin{array}{l}\text { Dastmalchi et al. } \\
\text { [14] }\end{array}$ & 9 & $\begin{array}{l}\text { Aerobic } \\
\text { Strength }\end{array}$ & 12 & $\begin{array}{l}\text { Type of muscle fiber } \\
\text { Quality of life } \\
\text { Functional capacity }\end{array}$ & Not reported & $\begin{array}{l}\uparrow \text { Type I Fiber } \\
\uparrow \text { Functional Capacity } \\
\uparrow \text { Quality of Life }\end{array}$ \\
\hline $\begin{array}{l}\text { Chung et al. } \\
\text { [47] }\end{array}$ & 37 & $\begin{array}{l}\text { Strength } \\
\text { Dynamic } \\
\text { Creatine } \\
\text { supplementation }\end{array}$ & 20 & $\begin{array}{l}\text { Functional capacity } \\
\text { Muscle strength } \\
\text { Quality of life } \\
\text { Pain and fatigue } \\
\text { Anxiety and depression }\end{array}$ & $\leftrightarrow \mathrm{CPK}$ & $\begin{array}{l}\uparrow \text { Functional capacity } \\
\uparrow \text { Muscle strength } \\
\leftrightarrow \text { Quality of life } \\
\leftrightarrow \text { Anxiety and depression } \\
\leftrightarrow \text { Pain and fatigue }\end{array}$ \\
\hline $\begin{array}{l}\text { Nader et al. } \\
{[21]}\end{array}$ & 8 & $\begin{array}{l}\text { Strength } \\
\text { Dynamic }\end{array}$ & 7 & $\begin{array}{l}\text { Genes related to } \\
\text { inflammation and } \\
\text { fibrosis }\end{array}$ & $\downarrow \mathrm{CPK}$ & $\begin{array}{l}\downarrow \text { Genes related to } \\
\text { inflammation and fibrosis } \\
\downarrow \text { Tissue fibrosis }\end{array}$ \\
\hline $\begin{array}{l}\text { Munters et al. } \\
{[12]}\end{array}$ & 9 & Aerobic & 12 & $\begin{array}{l}\text { Aerobic capacity } \\
\text { Activity of mitochondrial } \\
\text { enzymes }\end{array}$ & $\leftrightarrow \mathrm{CPK}$ & $\begin{array}{l}\uparrow \text { Aerobic capacity } \\
\uparrow \text { Activity of mitochondrial } \\
\text { enzymes }\end{array}$ \\
\hline $\begin{array}{l}\text { Munters et al. } \\
{[20]}\end{array}$ & 11 & Aerobic & 12 & $\begin{array}{l}\text { Aerobic capacity } \\
\text { Disability } \\
\text { Disease activity } \\
\text { Quality of life } \\
5 \text { MVC }\end{array}$ & $\leftrightarrow \mathrm{CPK}$ & $\begin{array}{l}\downarrow \text { Disease activity } \\
\uparrow \text { Muscle strength } \\
\uparrow \text { Quality of life } \\
\uparrow \text { Aerobic capacity } \\
\uparrow \text { Quality of life }\end{array}$ \\
\hline $\begin{array}{l}\text { Mattar et al. } \\
{[25]}\end{array}$ & 13 & $\begin{array}{l}\text { Strength } \\
\text { Dynamic } \\
\text { Vascular } \\
\text { occlusion }\end{array}$ & 12 & $\begin{array}{l}\text { Muscle strength } \\
\text { Functional capacity } \\
\text { Quality of life }\end{array}$ & $\leftrightarrow \mathrm{CPK} \leftrightarrow$ Aldolase & $\begin{array}{l}\uparrow \text { Muscle strength } \\
\uparrow \text { Functional capacity } \\
\uparrow \text { Quality of life }\end{array}$ \\
\hline $\begin{array}{l}\text { Munters et al. } \\
{[22]}\end{array}$ & 15 & Aerobic & 12 & $\begin{array}{l}\text { Aerobic capacity } \\
\text { Proteomic analysis } \\
\text { Molecular profile }\end{array}$ & $\leftrightarrow \mathrm{CPK}$ & $\begin{array}{l}\uparrow \text { Aerobic capacity } \\
\uparrow \text { Genes related to capillary growth, } \\
\text { mitochondrial biogenesis, protein } \\
\text { synthesis, cytoskeletal remodeling } \\
\text { and muscular hypertrophy } \\
\uparrow \text { Genes related to the immune } \\
\text { and inflammatory response and } \\
\text { sarcoplasmic reticulum stress }\end{array}$ \\
\hline
\end{tabular}

CPK creatine phosphokinase, DM dermatomyositis, $P M$ polymyositis, $M V C$ maximum voluntary contraction, $V_{2}$ peak oxygen consumption, $\uparrow:$ increase, $\leftrightarrow$ : no change, $\downarrow$ : decrease

a included patients with inclusion body myositis

${ }^{b}$ included patients with active disease 
Table 3 Physical exercise among patients with dermatomyositis, newly diagnosed polymyositis, clinically active disease, or some combination therein

\begin{tabular}{|c|c|c|c|c|c|c|c|}
\hline Author & $\begin{array}{l}\text { Patients } \\
(n)\end{array}$ & Disease activity & $\begin{array}{l}\text { Protocol } \\
\text { (Exercises) }\end{array}$ & $\begin{array}{l}\text { Time } \\
\text { (week) }\end{array}$ & Evaluated components & Inflammatory markers & Results \\
\hline Escalante et al. [9] & 5 & Active & $\begin{array}{l}\text { Strength } \\
\text { Dynamic }\end{array}$ & 8 & Isometric strength & $\leftrightarrow \mathrm{CPK}$ & $\begin{array}{l}\uparrow \text { Isometric } \\
\text { strength }\end{array}$ \\
\hline $\begin{array}{l}\text { Alexanderson } \\
\text { et al. [24] }\end{array}$ & 11 & Active & $\begin{array}{l}\text { Strength } \\
\text { Dynamic }\end{array}$ & 12 & $\begin{array}{l}\text { Muscle function } \\
\text { Quality of life }\end{array}$ & $\leftrightarrow \mathrm{CPK}$ & $\begin{array}{l}\uparrow \text { Muscle function } \\
\uparrow \text { Quality of life }\end{array}$ \\
\hline avarvu et al. [45] & 19 & Chronic/Active & $\begin{array}{l}\text { Strength } \\
\text { Dynamic }\end{array}$ & 3 & $\begin{array}{l}\text { Respiratory function } \\
\text { (Spirometry) } \\
\text { Muscle strength }\end{array}$ & $\leftrightarrow \mathrm{CPK}$ & $\begin{array}{l}\uparrow \text { Respiratory } \\
\text { function } \\
\uparrow \text { Muscle function }\end{array}$ \\
\hline Mattar et al. [29] & 3 & Active & $\begin{array}{l}\text { Strength } \\
\text { Aerobic }\end{array}$ & 12 & $\begin{array}{l}\text { Muscle strength } \\
\text { Functional capacity } \\
\text { Quality of life }\end{array}$ & $\leftrightarrow \mathrm{CPK} \leftrightarrow$ Aldolase & $\begin{array}{l}\uparrow \text { Muscle strength } \\
\uparrow \text { Functional } \\
\text { capacity } \\
\uparrow \text { Quality of life }\end{array}$ \\
\hline
\end{tabular}

CPK creatine phosphokinase, DM dermatomyositis, $P M$ polymyositis, $\uparrow:$ increase, $\leftrightarrow$ : no change

${ }^{a}$ Active disease but with chronic evolution

et al. [12] corroborated these findings by demonstrating that aerobic training over a 12 -week period effectively improved the aerobic capacity of patients with DM/PM and increased the activity of the mitochondrial enzymes in their skeletal muscles. Aerobic training also led to a change in muscle fiber type (increased type I fibers) in these patients as well as an increase in the cross-sectional area of the muscle, which contributed to improvements in aerobic capacity and decreases in muscle fatigue [14]. In addition, Munters et al. [20] demonstrated that aerobic training improves the overall health of patients with $\mathrm{DM} / \mathrm{PM}$ in a multicenter study; furthermore, improved aerobic capacity through training was associated with reduced disease activity.

Although aerobic training has important benefits for patients with DM/PM, the molecular effects of physical exercise on the skeletal muscles of these patients are unknown. Physical exercise might positively modulate the genetic profile of patients with DM/PM. Nader et al. [21] evaluated the genes related to inflammation and fibrosis in eight patients with DM/PM undergoing strength training. After 7 weeks of training, the expression levels of genes related to skeletal muscle inflammation and fibrosis were reduced, and these changes were accompanied by a reduction in tissue fibrosis among these patients. Similarly, Munters et al. [22] evaluated the effect of a 12-week aerobic training program on the molecular profile of the skeletal muscles of seven patients with DM/PM compared with eight controls. After 12 weeks, the patients undergoing training showed increased expression levels of genes related to capillary growth, mitochondrial biogenesis, protein synthesis, cytoskeletal remodeling, and muscle hypertrophy as well as decreased expression of genes related to inflammation, immune response, and endoplasmic reticulum stress [22]. These data suggest that the training activates an aerobic phenotype and promotes muscle growth as well as suppresses the inflammatory response in the muscles of these patients.

As with aerobic capacity, patients with DM/PM show a significant decrease in muscle strength, primarily in the proximal muscles, which in turn leads to functional impairment $[1,2]$. Several studies have demonstrated that physical training plays an important role in reversing the losses in muscle strength and function in patients with DM/PM [19, 23-25]. Escalante et al. [9] was the first to demonstrate an increase in muscle strength among three patients with DM/PM who engaged in physical training for 2 weeks. Based on these preliminary data, Wiesinger et al. [25] studied eight patients with DM/PM who participated in a physical training program for 6 months and observed increases in isometric strength, which led to improvements in activities of daily living (e.g., sitting down, standing up, and walking) in these patients. Alexanderson et al. [23] corroborated these data when they demonstrated that an intensive 7 -week physical training program led to increases in muscle strength, helping to improve the impairments and limitations in daily activities without increasing inflammatory markers.

Strength training with intensities ranging from 70 to $80 \%$ of one-repetition maximum (1RM) has been recommended to increase muscle strength and mass [26]. As an alternative to this type of exercise, the practice of low-intensity strength training (20 to $30 \%$ of $1 \mathrm{RM}$ ) combined with partial blood flow restriction likely induces similar improvements in muscle strength and hypertrophy in both healthy individuals and patients with chronic diseases [25-27]. Because patients with SAMs are generally unable to exercise at high intensities, this type of training is an alternative to conventional strength training. Mattar et al. [25] were the first to demonstrate that low-intensity strength training combined with partial blood flow restriction was a safe and effective method of increasing muscle strength, function, and 
mass and that it could lead to significant improvements in the quality of life of patients with DM/PM. These results suggest that this type of training act as a new non-pharmacological therapy to reverse the clinical manifestations associated with these diseases.

\section{Physical exercise among patients with DM/PM during clinical disease activity}

The data presented above lead us to believe that physical exercise is a powerful aid in improving the impaired physical abilities of patients with DM/PM. In addition, because inflammatory markers were not exacerbated in the studies presented, exercise training might be safe for these patients.

However, newly diagnosed patients and those with clinical disease activity are often fearful regarding the use of exercise training. Because patients present with a high degree of inflammation, fear remains about exercising during these periods.

Alexanderson et al. [28] evaluated the effect of intensive physical training performed at home five times per week over a 12-week period on the clinical disease activity of patients with DM/PM. After 12 weeks, significant increases were observed in muscle strength and function, which in turn led to an improvement in the quality of life of these patients. These authors suggested that this physical exercise program was safe because the inflammatory markers did not increase; therefore, exercise training was recommended for the rehabilitation of these patients. Similarly, Mattar et al. [29] conducted a case series study of three patients with clinical DM/PM activity and assessed the safety and effect of aerobic training combined with supervised strength training over a 12 -week period. After this period, physical training was well tolerated and safe (i.e., increases in creatine phosphokinase (CPK) and aldolase levels were not found). In addition, specific parameters of aerobic capacity, muscle function, and quality of life improved, suggesting that supervised physical training positively affects these parameters during clinical disease activity.

Alexanderson et al. [24] were the first to demonstrate that physical exercise is safe during this period for patients newly diagnosed with DM/PM. A total of 19 patients newly diagnosed with $\mathrm{DM} / \mathrm{PM}$ receiving high doses of prednisone were selected. The patients were randomized into a training group $(n=10)$ and a control group $(n=9)$. The patients in the training group were instructed to perform an intensive physical training program (five times per week for 12 weeks); the patients were then evaluated at the 24th, 52nd, 78th and 104th weeks. No significant differences were found between the training and control groups with regard to the parameters evaluated; however, intensive physical training was found to be safe for these patients because it did not exacerbate inflammation during the evaluated period, suggesting that exercise training is safe even for newly diagnosed patients.

\section{Physical exercise in patients with IBM}

Although the effects of physical training on patients with $\mathrm{DM} / \mathrm{PM}$ have been well described in the literature, few studies have evaluated the effect of physical training on patients with IBM.

Studies comparing the aerobic capacity of these patients with healthy controls are scarce. Because patients with IBM also present with significant impairments in their mitochondrial oxidative capacity [30, 31], studies are necessary to determine whether these patients have impaired aerobic capacity. To date, only one study has evaluated the effect of 12 weeks of stationary bicycle training combined with strength training on the aerobic capacity of seven patients with IBM (Table 4). After 12 weeks of physical training, a $38 \%$ increase in aerobic capacity was observed among these patients [32].

Like those with DM/PM, patients with IBM present with an important impairment in muscle strength as a characteristic of the disease [33, 34]. Spector et al. [35] examined five patients with IBM who completed a 12week progressive strength-training program. These authors did not observe an increase in the cross-sectional area of the muscle; however, a significant increase in muscle strength was shown without the exacerbation of inflammatory markers. Low-intensity strength training combined with partial blood flow restriction is also an important aid when reversing the losses in strength and muscular function as well as stimulating the increase of muscle mass in these patients. Gualano et al. [36] were the first authors to demonstrate that strength training combined with partial blood flow restriction for 12 weeks effectively and safely increased muscle strength (through the 1RM test), balance, and function as well as lead to $15.9,60$, and $4.7 \%$ increases in the cross-sectional area of muscle in a case study of a patient with IBM resistant to all types of treatment. In addition, there was an improvement in quality of life, varying from 18 to $600 \%$. In addition to these effects, the same research group [37] demonstrated that strength training combined with the partial restriction of blood flow for 12 weeks decreased the expression of the myostatin gene and increased the expression of endogenous myostatin inhibitors. These data might partially explain the increase in muscle mass observed in the aforementioned case study [36]. Corroborating the previous findings, Jorgensen et al. [38] examined a 74-year-old man with who participated in strength training combined with partial blood flow restriction over a 12week period. These authors observed substantial increases in mechanical muscle strength and gait speed, suggesting that this type of training reverses the losses in strength and functional capacity associated with these patients. 
Table 4 Physical exercise in patients with chronic inclusion body myositis

\begin{tabular}{|c|c|c|c|c|c|c|}
\hline Author & $\begin{array}{l}\text { Patients } \\
(n)\end{array}$ & $\begin{array}{l}\text { Protocol } \\
\text { (Exercises) }\end{array}$ & $\begin{array}{l}\text { Time } \\
\text { (week) }\end{array}$ & Evaluated Components & $\begin{array}{l}\text { Inflammatory } \\
\text { markers }\end{array}$ & Results \\
\hline Spector et al. [35] & 5 & $\begin{array}{l}\text { Strength } \\
\text { Dynamic }\end{array}$ & 12 & $\begin{array}{l}\text { Isometric strength } \\
3 \mathrm{MVC}\end{array}$ & $\begin{aligned} \leftrightarrow & \text { CPK } \\
\leftrightarrow & \text { Immune / } \\
& \text { inflammatory } \\
& \text { markers }\end{aligned}$ & $\begin{array}{l}\uparrow \text { Isometric strength } \\
\uparrow 3 \mathrm{MVC} \\
\leftrightarrow \text { Increased cross-sectional } \\
\quad \text { area }\end{array}$ \\
\hline Arnardottir et al. [39] & 7 & $\begin{array}{l}\text { Strength } \\
\text { Dynamic }\end{array}$ & 12 & Isometric strength & $\begin{aligned} \leftrightarrow & \text { CPK } \\
\leftrightarrow & \text { Cytokines } \\
\leftrightarrow & \text { Adhesion } \\
& \text { molecules }\end{aligned}$ & $\uparrow$ Isometric strength \\
\hline \multirow[t]{2}{*}{ Johnson et al. [32] } & 7 & Aerobic & 12 & $\begin{array}{l}\mathrm{VO}_{2} \text { peak } \\
\text { Functional Capacity }\end{array}$ & $\leftrightarrow \mathrm{CPK}$ & $\begin{array}{l}\uparrow \mathrm{VO}_{2} \text { peak } \\
\leftrightarrow \text { Functional capacity }\end{array}$ \\
\hline & 7 & $\begin{array}{l}\text { Strength } \\
\text { Dynamic }\end{array}$ & 16 & $\begin{array}{l}\text { Muscle strength } \\
\text { Functional capacity }\end{array}$ & $\leftrightarrow \mathrm{CPK}$ & $\begin{array}{l}\uparrow \text { Muscle strength } \\
\uparrow \text { Functional capacity }\end{array}$ \\
\hline Gualano et al. [36] & 1 & $\begin{array}{l}\text { Strength } \\
\text { Dynamic } \\
\text { With vascular } \\
\text { occlusion }\end{array}$ & 12 & $\begin{array}{l}\text { Muscle strength } \\
\text { Balance } \\
\text { Quality of life } \\
\text { Cross-sectional area }\end{array}$ & $\leftrightarrow \mathrm{CPK}$ & $\begin{array}{l}\uparrow \text { Muscle strength } \\
\uparrow \text { Balance } \\
\uparrow \text { Quality of life } \\
\uparrow \text { Cross-sectional area }\end{array}$ \\
\hline Santos et al. [37] & 1 & $\begin{array}{l}\text { Strength } \\
\text { Dynamic } \\
\text { With vascular } \\
\text { occlusion }\end{array}$ & 12 & $\begin{array}{l}\text { Myostatin gene } \\
\text { Myostatin inhibitor } \\
\text { genes }\end{array}$ & $\leftrightarrow \mathrm{CPK}$ & $\begin{array}{l}\downarrow \text { Myostatin gene } \\
\uparrow \text { Myostatin inhibitor genes }\end{array}$ \\
\hline Jorgensen et al. [38] & 1 & $\begin{array}{l}\text { Strength } \\
\text { Dynamic } \\
\text { With vascular } \\
\text { occlusion }\end{array}$ & 12 & $\begin{array}{l}\text { Isometric strength } \\
\text { Functional capacity } \\
\text { Gait speed }\end{array}$ & $\leftrightarrow \mathrm{CPK}$ & $\begin{array}{l}\uparrow \text { Isometric strength } \\
\uparrow \text { Functional capacity } \\
\uparrow \text { Gait speed }\end{array}$ \\
\hline
\end{tabular}

CPK creatine phosphokinase, MVC maximum voluntary contraction, $V \mathrm{O}_{2}$ peak oxygen consumption, $\uparrow:$ increase, $\leftrightarrow:$ no change

Physical exercise performed at home is also an important therapy for patients with IBM. Intensive home training ( 5 days per week for 12 weeks) was also found to be safe (no increase in creatine phosphokinase levels) and effective at increasing the muscle strength and function of these patients [39], suggesting that this practice effectively rehabilitates patients with IBM.

\section{Future prospects and final considerations}

SAMs are characterized by periods of clinical activity and remission. During clinical disease activity, patients present with a significant decrease in skeletal muscle strength, which remains lower throughout the lifespan. This decrease in strength leads to functional impairment and consequent decreases in daily activities, resulting in marked sedentary lifestyles among these patients.

The data presented in this review suggest that physical training is an important non-pharmacological tool for increasing muscle strength, improving functional impairment, and improving the quality of life of patients with SAMs. In addition, physical training likely improves the impaired aerobic capacity of patients with SAMs. This effect is likely associated with the ability of physical training to improve the molecular profile (thereby increasing the expression of the genes related to mitochondrial neoangiogenesis and biogenesis) and leading to increases in the activities of mitochondrial enzymes and the type I fibers in the skeletal muscle [12, 21, 22].
Additional studies are needed to better understand how physical exercise acts in the pathogenesis of SAMs. The causes of these diseases are not yet known; however, immune and nonimmune mechanisms are most likely involved [40-43]. Studies that demonstrate how physical exercise affects these parameters might help to understand how exercise training acts toward the clinical improvement of these diseases.

Clinical, controlled, and randomized studies of patients with IBM are necessary to show the real effects of physical exercise among this population. Physical training likely stimulates increases in muscle strength and improves the aerobic capacities of these patients; however, without an increase in the cross-sectional area of the muscle [32, 35, 39]. Strength training with vascular occlusion appears to efficiently increase strength, function, balance, and the cross-sectional area of muscle in these patients [36, 37]. Thus, this type of training is an alternative to conventional training that is capable of stimulating increases in the muscle mass of patients with IBM. Because these patients are generally resistant to drug therapy, the use of strength training with vascular occlusion is an important aid to minimize the clinical manifestations of this disease.

Studies have yet to evaluate the effect of physical exercise among patients with immune-mediated necrotizing myopathy; therefore, future trials should explore this area. 


\section{Conclusions}

The data presented in this review suggest that physical training is an important cal tool for increasing muscle strength, improving functional impairment, and improving the quality of life of patients with SAMs. In addition, physical training likely improves the impaired aerobic capacity of patients with SAMs.

\section{Abbreviations}

CPK: Creatine phosphokinase; DM: Dermatomyositis; IBM: Inclusion body myositis; PM: Polymyositis; RM: repetition maximum; SAMs: Systemic autoimmune myopathies; VO2 peak: Peak oxygen consumption

\section{Support}

FAPESP \#2017/13109-1 and Fundação Faculdade de Medicina to SKS.

\section{Authors' contributions}

All authors contributed equally to write and review the manuscript. All authors read and approved the final manuscript.

\section{Ethics approval and consent to participate}

Not applicable

\section{Competing interests}

The authors declare that they have no competing interests.

\section{Publisher's Note}

Springer Nature remains neutral with regard to jurisdictional claims in published maps and institutional affiliations.

\section{Author details}

${ }^{1}$ Division of Rheumatology, Faculdade de Medicina FMUSP, Universidade de Sao Paulo, Av. Dr. Arnaldo, 455, $3^{\circ}$ andar, sala 3150 - Cerqueira César, Sao Paulo 01246-903, Brazil. ²Division of Rheumatology, Hospital das Clinicas HCFMUSP, Faculdade de Medicina, Universidade de Sao Paulo, Sao Paulo, Brazil.

\section{Received: 20 March 2018 Accepted: 12 April 2018}

Published online: 24 May 2018

\section{References}

1. Feldman BM, Rider LG, Reed AM, Pachman LM. Juvenile dermatomyositis and other idiopathic inflammatory myopathies of childhood. Lancet. 2008; 371:2201-12.

2. Greenberg SA. Inflammatory myopathies: evaluation and management. Semin Neurol. 2008;28:241-9.

3. Dalakas MC. Review: an update on inflammatory and autoimmune myopathies. Neuropathol Appl Neurobiol. 2011;37:226-42.

4. Dimanckhie MM, Barohn R, Amato AA. Idiopathic inflammatory myopathies. Neurol Clin. 2014;32:595-628.

5. Partridge RE, Duthie JJ. Controlled trial of the effect of complete immobilization of the joints in rheumatoid arthritis. Ann Rheum Dis. 1963:22:91-9.

6. Lim MS, Park B, Kong IG, Sim S, Kim SY, Kim JH, et al. Leisure sedentary time is differentially associated with hypertension, diabetes mellitus, and hyperlipidemia depending on occupation. BMC Public Health. 2017;17:278-87.

7. Garelnabi M, Veledar E, Abramson J, White-Welkley J, Santanam N, Weintraub W, et al. Physical inactivity and cardiovascular risk: baseline observations from men and premenopausal women. J Clin Lab Anal. 2010;24:100-5

8. Hicks JE, Miller F, Plotz P, Chen TH, Gerber L. Isometric exercise increases strength and does not produce sustained creatinine phosphokinase increases in a patients with polymyositis. J Rheumatol. 1993;20:1399-401.

9. Escalante A, Miller $L$, Beardmore TD. Resistive exercise in the rehabilitation of polymyositis/dermatomyositis. J Rheumatol. 1993;41:1124-32.

10. Wiesinger GF, Quittan M, Aringer M, Seeber A, Volc-platzer B, Smolen J, et al. Improvement of physical fitness and muscle strength in polymyositis/dermatomyositis patients by a training programme. $\mathrm{Br}$ Rheumatol. 1998;37:196-200.
11. Wiesinger GF, Quittan M, Nuhr M, Volc-Platzer B, Ebenbichler G, Zehetgruber $\mathrm{M}$, et al. Aerobic capacity in adult dermatomyositis/polymyositis patients and healthy controls. Arch Phys Med Rehabil. 2000;81:1-5.

12. Alemo Munters L, Dastmalchi M, Katz A, Esbjörnsson M, Loell I, Hanna B, et al. Improved exercise performance and increased aerobic capacity after endurance training of patients with stable polymyositis and dermatomyositis. Arthritis Res Ther. 2013;15:83-96.

13. Bertolucci F, Neri R, Dalise S, Venturi M, Rossi B, Chisari C. Abnormal lactate levels in patients with polymyositis and dermatomyositis: the benefits of a specific rehabilitative program. Eur J Phys Rehabil Med. 2014;50:161-9.

14. Dastmalchi M, Alexanderson H, Loell I, Stahlberg M, Borg K, Lundberg IE, et al. Effect of physical training on the proportion of slow-twitch type I muscle fibers, a novel nonimmune-mediated mechanism for muscle impairment in polymyositis or dermatomyositis. Arthritis Rheum. 2007;57:1303-10.

15. Moraes MT, De Souza FH, De Barros TB, Shinjo SK. An analysis of metabolic syndrome in adult dermatomyositis with a focus on cardiovascular disease. Arthritis Care Res. 2013:65:793-9.

16. Limaye V, Hakendorf P, Woodman RJ, Blumbergs P, Roberts-Thomson P. Mortality and its predominant causes in a large cohort of patients with biopsy-determined inflammatory myositis. Intern Med J. 2012;42:191-8.

17. Ladenvall P, Persson CU, Mandalenakis Z, Wilhelmsen L, Grimby G, Svärdsudd K, et al. Low aerobic capacity in middle-aged men associated with increased mortality rates during 45 years of follow-up. Eur J Prev Cardiol. 2016;23:1557-64

18. Sui X, LaMonte MJ, Laditka JN, Hardin JW, Chase N, Hooker SP, et al. Cardiorespiratory fitness and adiposity as mortality predictors in older adults. JAMA. 2007;298:2507-16.

19. Wiesinger GF, Quittan M, Graninger M, Seeber A, Ebenbichler G, Sturm B, Kerschan K, Smolen J, Graninger W. Benefit of 6 months long-term physical training in polymyositis/dermatomyositis patients. $\mathrm{Br} J$ Rheumatol. 1998;37:1338-42.

20. Alemo Munters L, Dastmalchi M, Andgren V, Emilson C, Bergegård J, Regardt $M$, et al. Improvement in health and possible reduction in disease activity using endurance exercise in patients with established polymyositis and dermatomyositis: a multicenter randomized controlled trial with a 1-year open extension followup. Arthritis Care Res (Hoboken). 2013;65:1959-68.

21. Nader GA, Dastmalchi M, Alexanderson H, Grundtman C, Gernapudi R, Esbjörnsson $\mathrm{M}$, et al. A longitudinal, integrated, clinical, histological and mRNA profiling study of resistance exercise in myositis. Mol Med. 2010;16:455-64.

22. Munters LA, Loell I, Ossipova E, Raouf J, Dastmalchi M, Lindroos E, et al. Endurance exercise improves molecular pathways of aerobic metabolism in patients with myositis. Arthritis Rheumatol. 2016:68:1738-50.

23. Alexanderson $\mathrm{H}$, Dastmalchi $\mathrm{M}$, Esbjornsson-Liljedahl M, Opava $\mathrm{CH}$, Lundberg IE. Benefits of intensive resistance training in patients with chronic polymyositis or dermatomyositis. Arthritis Rheum. 2007;57:768-77.

24. Alexanderson $\mathrm{H}$, Stenström $\mathrm{CH}$, Jenner $\mathrm{G}$, Lundberg I. The safety of a resistive home exercise program in patients with recent onset active polymyositis or dermatomyositis. Scand J Rheumatol. 2000:29:295-301.

25. Mattar MA, Gualano B, Perandini LA, Shinjo SK, Lima FR, Sá-Pinto LA, et al. Safety and possible effects of low-intensity resistance training associated with partial blood flow restriction in polymyositis and dermatomyositis. Arthritis Res Ther. 2014;16:473.

26. Scott BR, Loenneke JP, Slattery KM, Dascombe BJ. Exercise with blood flow restriction: an updated evidence-based approach for enhanced muscular development. Sports Med. 2015;45(3):313-25.

27. Scott BR, Loenneke JP, Slattery KM, Dascombe BJ. Blood flow restricted exercise for athletes: a review of available evidence. J Sci Med Sport. 2016;19:360-7.

28. Alexanderson $\mathrm{H}$, Stenström CH, Lundberg I. Safety of a home exercise programme in patients with polymyositis and dermatomyositis: a pilot study. Rheumatology (Oxford). 1999:38:608-11.

29. Mattar MA, Gualano B, Roschel H, Perandini LA, Dassouki T, Lima FR, Shinjo SK, de Sá Pinto AL. Exercise as an adjuvant treatment in persistent active polymyositis. J Clin Rheumatol. 2014;20:11-5.

30. Lindgren U, Roos S, Hedberg Oldfors C, Moslemi AR, Lindberg C, et al. Mitochondrial pathology in inclusion body myositis. Neuromuscul Disord. 2015:25:281-8.

31. Joshi PR, Vetterke M, Hauburger A, Tacik P, Stoltenburg G, Hanisch F. Functional relevance of mitochondrial abnormalities in sporadic inclusion body myositis. J Clin Neurosci. 2014;21:1959-63. 
32. Johnson LG, Collier KE, Edwards DJ, Philippe DL, Eastwood PR, Walters SE, et al. Improvement in aerobic capacity after an exercise program in sporadic inclusion body myositis. J Clin Neuromuscul Dis. 2009;10:178-84.

33. Gallay L, Petiot P. Sporadic inclusion-body myositis: recent advances and the state of the art in 2016. Rev Neurol (Paris). 2016;172:581-6.

34. Needham M, Mastaglia FL. Sporadic inclusion body myositis: a review of recent clinical advances and current approaches to diagnosis and treatment. Clin Neurophysiol. 2016;127:1764-73.

35. Spector SA, Lemmer JT, Koffman BM, Fleisher TA, Feuerstein IM, Hurley BF, et al. Safety and efficacy of strength training in patients with sporadic inclusion body myositis. Muscle Nerve. 1997;20:1242-8.

36. Gualano B, Neves M Jr, Lima FR, Pinto AL, Laurentino G, Borges C, et al. Resistance training with vascular occlusion in inclusion body myositis: a case study. Med Sci Sports Exerc. 2010;42:250-4.

37. Santos AR, Neves MT Jr, Gualano B, Laurentino GC, Lancha AH Jr. Ugrinowitsch C, et al. Blood flow restricted resistance training attenuates myostatin gene expression in a patient with inclusion body myositis. Biol Sport. 2014;31:121-4.

38. Jørgensen AN, Aagaard P, Nielsen JL, Frandsen U, Diederichsen LP. Effects of blood-flow-restricted resistance training on muscle function in a 74-year-old male with sporadic inclusion body myositis: a case report. Clin Physiol Funct Imaging. 2016;36:504-9.

39. Arnardottir S, Alexanderson H, Lundberg IE, Borg K. Sporadic inclusion body myositis: pilot study on the effects of a home exercise program on muscle function, histopathology and inflammatory reaction. J Rehabil Med. 2003;35:31-5.

40. Grundtman C, Malmström V, Lundberg IE. Immune mechanisms in the pathogenesis of idiopathic inflammatory myopathies. Arthritis Res Ther. 2007;9:208-20

41. Rayavarapu S, Coley W, Kinder TB, Nagaraju K. Idiopathic inflammatory myopathies: pathogenic mechanisms of muscle weakness. Skelet Muscle. 2013;3:13-26.

42. Lightfoot AP, Nagaraju K, MCArdle A, Cooper RG. Understanding the origin of non-immune cell-mediated weakness in the idiopathic inflammatory myopathies - potential role of ER stress pathways. Curr Opin Rheumatol. 2015;27:580-5.

43. Ceribelli A, De Santis M, Isailovic N, Gershwin ME, Selmi C. The immune response and the pathogenesis of idiopathic inflammatory myositis: a critical review. Clin Rev Allergy Immunol. 2017;52:58-70.

44. Heikkila S, Viitanen JV, Kautiainen $\mathrm{H}$, et al. Rehabilitation in myositis. Physiother. 2001;87:301-9.

45. Varjú C, Pethö E, Kutas R, Czirják L. The effect of physical exercise following acute disease exacerbation in patients with dermato/polymyositis. Clin Rehabil. 2003;17:83-7.

46. Harris-Love MO. Safety and efficacy of submaximal eccentric strength training for a subject with polymyositis. Arthritis Rheum. 2005;53:471-4.

47. Chung YL, Alexanderson H, Pipitone N, Morrison C, Dastmalchi M, StåhlHallengren C, et al. Creatine supplements in patients with idiopathic inflammatory myopathies who are clinically weak after conventional pharmacologic treatment: six-month, double-blind, randomized, placebocontrolled trial. Arthritis Rheum. 2007;57:694-702.

\section{Ready to submit your research? Choose BMC and benefit from:}

- fast, convenient online submission

- thorough peer review by experienced researchers in your field

- rapid publication on acceptance

- support for research data, including large and complex data types

- gold Open Access which fosters wider collaboration and increased citations

- maximum visibility for your research: over $100 \mathrm{M}$ website views per year

At BMC, research is always in progress.

Learn more biomedcentral.com/submissions 